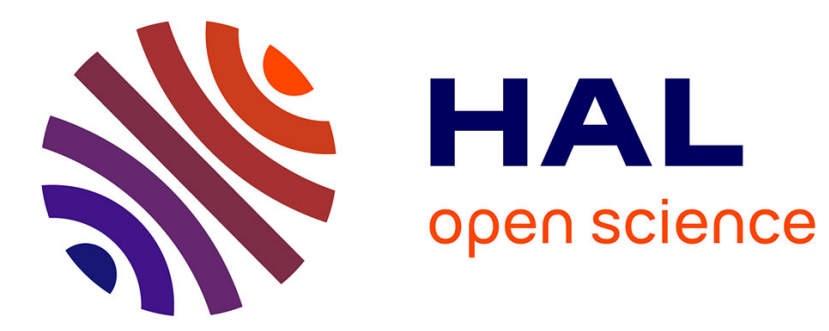

\title{
Detection of oxygen traces in nitrogen and hydrogen-rich atmosphere
}

\author{
Stéphanie Albert, Jean-Paul Viricelle, Guy Tournier, Philippe Breuil, \\ Christophe Pijolat
}

\section{- To cite this version:}

Stéphanie Albert, Jean-Paul Viricelle, Guy Tournier, Philippe Breuil, Christophe Pijolat. Detection of oxygen traces in nitrogen and hydrogen-rich atmosphere. Sensors and Actuators B: Chemical, 2009, 139 (2), pp.298-303. 10.1016/j.snb.2009.03.035 . hal-00409703

\section{HAL Id: hal-00409703 https://hal.science/hal-00409703}

Submitted on 12 Aug 2009

HAL is a multi-disciplinary open access archive for the deposit and dissemination of scientific research documents, whether they are published or not. The documents may come from teaching and research institutions in France or abroad, or from public or private research centers.
L'archive ouverte pluridisciplinaire HAL, est destinée au dépôt et à la diffusion de documents scientifiques de niveau recherche, publiés ou non, émanant des établissements d'enseignement et de recherche français ou étrangers, des laboratoires publics ou privés. 
JPV-Sensors \& Actuators B, 2009, 139(2), 298-303, doi:10.1016/j.snb.2009.03.035

Detection of oxygen traces in nitrogen and hydrogen-rich atmosphere

\author{
SALBERT( ${ }^{(\mathrm{A})}$, J.P. VIRICELLE $^{\left(\mathrm{B}^{*}\right)}$, G TOURNIER$^{(\mathrm{B})}$, P BREUIL $^{(\mathrm{B})}$, C PIJ OLAT $^{(\mathrm{B})}$ \\ (a) Institut Charles Gerhardt Montpellier, UMR 5253 CNRS-UM2-ENSCM-UM1, Equipe \\ Physico-chimie des Matériaux Désordonnés et Poreux (PMDP), Université Montpellier 2- \\ Bat. 15-CCoo3, Place Eugène Bataillon, 34095 Montpellier Cedex 5, France \\ (b) Département MICC, Centre SPIN, Ecole Nationale Supérieure des Mines, LPMG-UMR \\ 5148, 158 cours Fauriel, 42023 Saint Etienne Cedex 02, France \\ (*) (viricelle@emse.fr)
}

Paper (CBST 172) presented at the International Meeting of Chemical Sensors 2008 (IMCS12), July 13-16 2008, Columbus, OH, USA.

\begin{abstract}
Tin oxide sensors are evaluated to detect traces of oxygen in the range $0-100 \mathrm{ppm}$ both in nitrogen and hydrogen ( $4.5 \mathrm{vol} \% \mathrm{H}_{2}$ in $\mathrm{N}_{2}$ ) atmospheres. In nitrogen, significant relative responses to oxygen are measured at $623 \mathrm{~K}$ and $723 \mathrm{~K}$. However, at lower temperature, $523 \mathrm{~K}$, the response strongly decreases. In the presence of hydrogen, on the contrary, interesting responses are measured at $523 \mathrm{~K}$. At higher temperature, $623 \mathrm{~K}$ and $723 \mathrm{~K}$, on one hand $\mathrm{SnO}_{2}$ sensors begin to reduce, and on the other hand, oxygen is partly consumed by reaction with hydrogen. Oxygen trace detection $\left(5^{-100} \mathrm{ppm}\right)$ is thus only possible in hydrogen atmosphere (4.5 vol\% $\mathrm{H}_{2}$ ) at $523 \mathrm{~K}$.

Keywords:

tin oxide, sensor, oxygen, hydrogen
\end{abstract}

\title{
Introduction
}

Today, the detection of gas traces (such as $\mathrm{CO}, \mathrm{O}_{2}$, etc.) in atmospheres containing hydrogen is of great interest, in particular for fuel cells application [1], [2] and [3]. Currently, several commercial sensors are dedicated to oxygen traces detection for various applications.

Electrochemical probes offer a wide range of oxygen concentration detection, notably that of Figaro GS oxygen sensor, typically used as oxygen sensor in hydrogen-based atmosphere [4]. These electrochemical probes have the advantage to exhibit low cross-sensitivity to the hydrogen gas, which means that their oxygen response is not dependant on hydrogen content. However, they work at temperatures close to the ambient and cannot be used for in situ measurements with temperature ranging from $523 \mathrm{~K}$ to $723 \mathrm{~K}$. In contrast, yttria-stabilized zirconia (YSZ) oxygen sensors must be used at high temperature $(T>873 \mathrm{~K})$ to insure a satisfactory electric conductivity of YSZ sensing material. However, they are also sensitive to hydrogen and to hydrocarbons because gas combustion in the presence of oxygen occurs locally in the neighborhood of the sensing element. Consequently, the detected quantity of oxygen is usually strongly underestimated by these sensors [5]. Sensors made of semiconducting materials have also been developed for the detection of oxygen in various gases as their electrical conductivity varies with the partial pressure of oxygen. Among them, zinc oxide and cerium oxide sensors, both $\mathrm{n}$ type semiconductors, have been studied. The former for measuring micro-concentration of oxygen (from $10^{-6} \mathrm{vol} \%$ to $10^{-1} \mathrm{vol} \%$ ) presents good chemical stability, no sensitivity to hydrogen and can be used between $293 \mathrm{~K}$ and $1390 \mathrm{~K}$. The latter has a sensitivity to $\mathrm{O}_{2}$ coming from its non-stoichiometry that induces a good electrical mobility. Unfortunately, the possible effects of interfering gases, in particular hydrogen, on these sensors have not been clarified yet [6] and [7]. If it is indeed important to know the range of measured $\mathrm{O} 2$ concentrations and the working temperatures, it is also 
necessary to study and understand the behavior of the sensors, especially in terms of deterioration, in a gaseous atmosphere containing hydrogen [8] and [9]. While gas detection in ambient air has been the concern of many studies, the potentiality of oxygen traces detection by tin dioxide, the most widely used material for semiconductor gas sensor, as well as the stability of these sensors in nitrogen or with hydrogen ( $4.5 \mathrm{vol} \%$, balanced in $\mathrm{N}_{2}$ ), have been scarcely studied and are the subject of this contribution. After a thermodynamic study of $\mathrm{H}_{2} / \mathrm{O}_{2}$ and $\mathrm{H}_{2} / \mathrm{O}_{2} / \mathrm{SnO}_{2}$ systems to determine the gas equilibrium concentrations and $\mathrm{SnO}_{2}$ stability domain, experimental results with sensors are presented.

\section{Experimental}

\section{$\mathrm{SnO}_{2}$ sensor preparation}

Sensing elements are constituted by a tin oxide thick film $(2 \mathrm{~mm} \times 4 \mathrm{~mm})$ deposited by screen-printing (Aurel C890 machine) onto a-alumina substrates

$(38.1 \mathrm{~mm} \times 5.1 \mathrm{~mm} \times 0.381 \mathrm{~mm})$. The screen-printing ink was prepared with a home-made tin oxide paste. $\mathrm{SnO}_{2}$ layers were annealed for $12 \mathrm{~h}$ at $1073 \mathrm{~K}\left(10^{\circ} \mathrm{min}^{-1}\right)$ in air before being used. For electrical measurements purpose, two screen-printed gold electrodes $(2 \mathrm{~mm} \times 1 \mathrm{~mm})$ with a thickness of about $1 \mu \mathrm{m}$ were also deposited from commercially available paste on the front side (Fig. 1).

Test bench and experiment description

In this study, the sensors were directly placed in a tubular furnace, on a sample holder allowing electrical connections with gold wires. The sensor temperature was fixed by the furnace which constitutes the main part of the test bench. Measurements were performed at $523 \mathrm{~K}, 623 \mathrm{~K}$ and $723 \mathrm{~K}$.

Experiments were carried out either in dry $\mathrm{N}_{2}$ or in $\mathrm{H}_{2}-\mathrm{N}_{2}$ atmospheres ( $4.5 \mathrm{vol} \% \mathrm{H}_{2}$ ) to detect various oxygen concentrations ranging from 5 to $100 \mathrm{ppm}$. Three starting gas feeds were used: $\mathrm{N}_{2}$ (impurities: $\left[\mathrm{H}_{2} \mathrm{O}\right]<3 \mathrm{ppm},\left[\mathrm{O}_{2}\right]<2 \mathrm{ppm}$ and $\left[\mathrm{C}_{\mathrm{n}} \mathrm{H}_{\mathrm{n}}\right]<0.5 \mathrm{ppm}$ ), $10 \% \mathrm{H}_{2}$ balanced in $\mathrm{N}_{2}$ (Air Liquide) and a homemade mixture of $2150 \mathrm{ppm}$ of $\mathrm{O}_{2}$ in $\mathrm{N}_{2}$. Mass flow meters (Brooks Instrument) monitored by computer (software ${ }^{\odot}$ Labview) were placed at the entrance of the furnace to control the concentrations of the different gases. The tests were made with a total gas flow of $5 \mathrm{l} / \mathrm{h}$. Before starting the experiments, a primary vacuum was set in the bench in order to remove residual oxygen. However, it was difficult to reach concentrations lower than a few ppm (2-5). To limit the possible leaks, all the connections between the bench and the gas inlets were made of stainless steel and valves stop were positioned upstream to each flow meter. A SYSTECH Instrument 910 oxygen probe was placed at the exit of the furnace to control the oxygen concentration.

Material characterization and sensor performance measurements

In order to analyse $\mathrm{SnO}_{2}$ sensing element stability, X-ray diffraction analysis was carried out with a Siemens D 5000 diffractometer (Cu Ka radiation, $1.5406 \AA$ wavelength, with acquisition parameters of $2 \theta=15^{-80^{\circ}}$ and a step of $0.005^{\circ}$ ) on samples obtained after different tests at various temperatures and gaseous atmospheres.

The conductance " $G$ " (in $\mathrm{S}$ ) of $\mathrm{SnO}_{2}$ sensors was measured by a Keithley 6430 apparatus with two gold wires fixed on gold electrodes. To compare the sensor responses at different temperatures, the relative sensor response to oxygen at a fixed temperature $T$ was defined by $\left(G_{0}-G\right) / G$, where $G$ is the conductance of the sensor under target gas with oxygen (either in $\mathrm{N}_{2}$ or $\mathrm{N}_{2}-\mathrm{H}_{2}$ atmosphere) and $G_{0}$ is the baseline conductance under oxygen free nitrogen or hydrogen carrier gas.

\section{Thermodynamic study}

A thermodynamic study of the systems $\mathrm{H}_{2} / \mathrm{O}_{2}$ and $\mathrm{SnO}_{2} / \mathrm{H}_{2} / \mathrm{O}_{2}$ was first performed to understand the reactivity of the system $\mathrm{H}_{2}-\mathrm{O}_{2}$ and the stability of $\mathrm{SnO}_{2}$ under the experimental conditions. Calculations were performed with $\odot$ Thermodata software (Thermodata-INPG-CNRS-Grenoble-France). 


\section{System $\mathrm{H}_{2} / \mathrm{O}_{2}$}

The reactivity of the system $\mathrm{H}_{2}-\mathrm{O}_{2}$ with temperature was studied for oxygen contents of $5 \mathrm{ppm}, 100 \mathrm{ppm}, 2.25 \times 10^{4} \mathrm{ppm}$ and $21 \times 10^{4} \mathrm{ppm}$ in $\mathrm{H}_{2}$ atmosphere $(4.5 \mathrm{vol} \%$ balanced in $\mathrm{N}_{2}$ ). In the temperature range $300-1200 \mathrm{~K}$, a total reaction is observed according to the equation:

$$
0.5 \mathrm{O}_{2}+\mathrm{H}_{2}=\mathrm{H}_{2} \mathrm{O}
$$

All oxygen is consumed in the domain $5^{-2.25} \times 10^{4} \mathrm{ppm}$. For example, in Fig. 2a with $5 \mathrm{ppm}$ of $\mathrm{O} 2,10 \mathrm{ppm}$ of $\mathrm{H} 2 \mathrm{O}$ is produced, and in Fig. 2b, for an oxygen concentration of $2.25 \times 10^{4} \mathrm{ppm}$ in $4.5 \mathrm{vol} \% \mathrm{H}_{2}$, the reaction is total: $\mathrm{H}_{2}$ and $\mathrm{O}_{2}$ are completely consumed and the concentration of $\mathrm{H}_{2} \mathrm{O}$ is $4.5 \mathrm{vol} \%$. It is important to note that the thermodynamic study is realized in static and not dynamic environment, contrary to experimental study presented in part IV.

System $\mathrm{SnO}_{2} / \mathrm{H}_{2} / \mathrm{O}_{2}$

The variation of the reduction temperature of $\mathrm{SnO}_{2}$ in $\mathrm{H}_{2}\left(4.5\right.$ vol\%) $-\mathrm{N}_{2}$ atmosphere was studied in our experimental conditions. Following the reaction (1) one may write:

$$
0.5 \mathrm{SnO}_{2}+\mathrm{H}_{2}=0.5 \mathrm{Sn}+\mathrm{H}_{2} \mathrm{O}
$$

Results are presented in Fig. 3a and b. For an oxygen concentration of 5 ppm (Fig. 3a), SnO2 reduction is total from $400 \mathrm{~K}$ and the oxygen is completely consumed in all the temperature range. The temperature at which the reduction is total is shifted to $450 \mathrm{~K}$ for oxygen concentrations of $100 \mathrm{ppm}$ with always an entire consumption of $\mathrm{O} 2$. The reduction is displaced towards higher temperatures because the environment becomes less reducing. Thus, with the highest oxygen content in our experiment (100 ppm), in the 523-723 K temperature range, a total reduction of $\mathrm{SnO}_{2}$ to metallic $\mathrm{Sn}$ should be observed with a complete consumption of the oxygen initially introduced. To obtain a thermodynamic stability of $\mathrm{SnO}_{2}$ in our conditions, at least $1000 \mathrm{ppm}$ of oxygen in $4.5 \mathrm{vol} \% \mathrm{H}_{2}$ would be required as the reduction of tin dioxide begins only at around $700 \mathrm{~K}$ in these conditions (Fig. $3 \mathrm{~b}$ ). As a conclusion, in our conditions, 4.5 vol\% $\mathrm{H}_{2}$ balanced with $\mathrm{N}_{2}$, and $\mathrm{O}_{2}$ concentration in the range of $0-100 \mathrm{ppm}$, a total consumption of oxygen according to reaction (1) and a total reduction of $\mathrm{SnO} 2$ according to reaction (2) should be observed at thermodynamic equilibrium. However, our experiments (part IV) are conducted under continuous gas flow. Therefore, kinetics will defined the oxygen concentration and the reduction state of $\mathrm{SnO}_{2}$.

\section{Experimental results}

\section{Calibration of the test bench}

To calibrate the test bench, a SYSTECH Instrument probe was positioned at the exit of the furnace to measure the real oxygen concentration at the outlet, when we inject, at the inlet, concentrations in the range $\mathrm{O}-10 \mathrm{ppm}$, either in $\mathrm{N}_{2}$ or $\mathrm{H}_{2}$ carrier gas. It was checked that the measurement of the oxygen concentration by the commercial probe was not significantly influenced by the nature of the carrier gas. Tests were carried out without and with a sensor inside the furnace in order to investigate if the presence of a sensor changes the oxygen concentrations measured at the outlet.

Measurements conducted at various temperatures are reported in Table 1. At $293 \mathrm{~K}$, both in nitrogen or 4.5 vol\% hydrogen, the oxygen concentrations measured by the electrochemical probe are similar to the injected ones. For low injected concentrations ( 0 and $5 \mathrm{ppm}$ ), the measurements of the probe are influenced by the residual oxygen content (4-6 ppm) in the test bench. This explains that measured values are higher than injected ones. For experiments performed in nitrogen, similar results were obtained for all temperatures in the range 293$723 \mathrm{~K}$. On the contrary, with $4.5 \mathrm{vol} \% \mathrm{H} 2$, at $523 \mathrm{~K}$, a significant decrease of the values read by the probe is observed (for example $81 \mathrm{ppm}$ for $100 \mathrm{ppm}$ injected), which can be attributed to a significant oxygen consumption via reaction (1) in the furnace, in agreement with the 
thermodynamic study. At $723 \mathrm{~K}$, the probe does not detect significant oxygen concentration (4 ppm). When hydrogen flow is stopped and replaced by nitrogen (last 2 points in Table 1), the detected oxygen content tends to return to the injected value (100 ppm) with a slow kinetics (gas flow effect).

The same kind of tests was carried out with a $\mathrm{SnO}_{2}$ sensor in the furnace, for $4.5 \mathrm{vol} \% \mathrm{H}_{2}$ atmosphere; results are presented in Table 2. The oxygen contents measured by the probe at the furnace exit are always smaller when a sensor is present (example at $523 \mathrm{~K}: 47 \mathrm{ppm}$ with the sensor, compared to $81 \mathrm{ppm}$ without the sensor, for $100 \mathrm{ppm}$ injected). This phenomenon indicates a supplementary consumption of oxygen by the sensor itself, as a result of $\mathrm{SnO}_{2}$ catalytic activity.

As a conclusion, in the temperature range 523-723 $\mathrm{K}$ and in the presence of $4.5 \mathrm{vol} \%$ of hydrogen, strong oxygen consumption occurs in the furnace, which is enhanced by the presence of $\mathrm{a} \mathrm{SnO}_{2}$ sensor. As a result, there is a high gradient of oxygen concentration between the injected values (inlet) and measured ones by the probe (outlet). The local oxygen concentration around the sensing layer cannot be accurately determined. Consequently, in the following sections of this paper, except if it is mentioned, the indicated oxygen concentration will be the injected ones at entrance of the bench.

\section{Sensor tests in nitrogen carrier gas}

In this part, performances of $\mathrm{SnO}_{2}$ sensors were investigated at $523 \mathrm{~K}, 623 \mathrm{~K}$ and $723 \mathrm{~K}$. For the first measurements at $523 \mathrm{~K}$, oxygen concentrations of $5,15,30,5 \mathrm{O}$ and $100 \mathrm{ppm}$ are injected during $1 \mathrm{~h}$. This cycle of injections was reproduced two times (Fig. 4). The sensor presents a good response to oxygen and conductance decreases with increasing $\mathrm{O} 2$ concentration, according to the well-known detection mechanism of tin oxide sensors for oxidizing gas. Except a difference for the first injection of $5 \mathrm{ppm}$ in initial cycle, explained by residual oxygen in inlet pipe, reproducible signals are measured.

Fig. 5 shows the dynamic electrical response of sensors in N2 atmosphere for several injection cycles obtained at $623 \mathrm{~K}$, for $\mathrm{O}_{2}$ concentration in the range $5^{-100} \mathrm{ppm}$. Here again, except for the first cycle, the sensor responses are reproducible. Sensor responses at $623 \mathrm{~K}$ are higher than the ones obtained at $540 \mathrm{~K}$; the conductance decreases more strongly with increasing $\mathrm{O}_{2}$ concentration. The sensor responses obtained at $723 \mathrm{~K}$ are in the same conductance range as the one measured at $623 \mathrm{~K}$.

Relative responses of the sensor expressed by $\left(G_{0}-G\right) / G$ are presented in Fig. 6, as a function of $\mathrm{O}_{2}$ concentration and of temperature. High oxygen responses are observed at $623 \mathrm{~K}$ and $723 \mathrm{~K}$ in comparison to the ones at $523 \mathrm{~K}$. Significant relative responses are measured, proving the potentialities of tin oxide sensors for detection of oxygen in the studied concentration range $5^{-100} \mathrm{ppm}$, in nitrogen carrier gas.

Sensor tests in the presence of $\mathrm{H}_{2}\left(4.5 \mathrm{vol} \%\right.$ in $\left.\mathrm{N}_{2}\right)$

In this part, potentiality of $\mathrm{SnO}_{2}$ sensors for the detection of oxygen traces in a hydrogenated environment is presented.

Responses at $523 \mathrm{~K}$ for three cycles of $\mathrm{O}_{2}$ injection are shown in Fig. 7. The sensors present good responses with increasing sensibilities for increasing $\mathrm{O}_{2}$ content $(5,30$ and $100 \mathrm{ppm})$. As for previous test, excepted for the first injection of the initial cycle, responses are reproducible. The observed behavior is the same as in $\mathrm{N}_{2}$ atmosphere. However, in nitrogen, the measured quantities of $\mathrm{O}_{2}$ by the SYSTECH Instrument probe were close to those injected, contrary to what it is observed in a hydrogenated atmosphere. The values measured at the exit of the bench are 3,12 and $47 \mathrm{ppm}$, respectively for nominal values at the entrance of 5, 30 and $100 \mathrm{ppm}$ (Table 2). Moreover, at $523 \mathrm{~K}, \mathrm{SnO} 2$ begins to be reduced to metallic tin as proved by the light grey coloration of the sensing layer and in agreement with thermodynamic calculations [3]. Nethertheless, X-ray analysis of $\mathrm{SnO}_{2}$ sensor layer after test at $523 \mathrm{~K}$ does not allow to detect any reduction phenomenon; besides characteristic peaks of alumina (sensor substrate) and gold (electrodes), only $\mathrm{SnO}_{2}$ phase is observed. No metallic tin can be seen. Sensor responses measured at $623 \mathrm{~K}$ in $4.5 \mathrm{vol} \% \mathrm{H}_{2}$ as a function of time, for the same oxygen nominal injections as previously, 5, 30 and 100 ppm, are reported in Fig. 8. The 
measurements are reproducible over three cycles. A significant response is still observed for $100 \mathrm{ppm} \mathrm{O}_{2}$ injection, but the responses to 5 and $30 \mathrm{ppm}$ injections are quite weak. No phase reduction of $\mathrm{SnO}_{2}$ into metallic tin was observed by X-rays analysis in spite of a dark coloration of the sensing element. This means, that at $523 \mathrm{~K}$ and $623 \mathrm{~K}$, a partial reduction of $\mathrm{SnO}_{2}$ probably occurs, but it remains limited to the surface.At $723 \mathrm{~K}$, the sensor presents no more sensitivity to oxygen. At the end of the measurement, the sensitive element became black. X-ray analysis confirms the degradation (reduction) of the tin dioxide sensing element. Tin (Sn) and tin oxide $\mathrm{SnO}$ can be observed as well as AuSn, compound resulting from reaction with gold electrodes. Alumina phase corresponds to the sensor substrate (Fig. 9). Relative responses measured both in nitrogen and 4.5 vol\% hydrogen are summarized in Fig. 10. In order to compare the results, the indicated oxygen concentrations are the measured concentrations at the furnace outlet. It is important to remind that these outlet concentrations are similar to the injected ones for experiments in nitrogen. However, for hydrogen experiments, outlet measured values are strongly lowered as reported previously (Table 2). Especially, the oxygen content is close to 0 at $723 \mathrm{~K}$, whatever the injected concentration is (5, 30 or $100 \mathrm{ppm})$.

In $\mathrm{N}_{2}$ environment, significant relative response were obtained at $623 \mathrm{~K}$ and $723 \mathrm{~K}$. At lower temperature, $523 \mathrm{~K}$, the sensibility is quite low. In the presence of hydrogen, it emerges from Fig. 10 that at $523 \mathrm{~K}$ and $623 \mathrm{~K}$, the sensitivities of the sensors to oxygen are quite more important than in nitrogen. At $723 \mathrm{~K}$, no response is measured as oxygen is completely converted in the furnace. Furthermore, in agreement with the thermodynamic study showing a reduction of tin dioxide in metallic tin beginning at $380 \mathrm{~K}$ for $5 \mathrm{ppm}$ of oxygen, the reduction of $\mathrm{SnO}_{2}$ layer is confirmed by X-rays diffraction analysis at $723 \mathrm{~K}$. The reduction of the sensitive element is also correlated to its change of coloration which changes from light grey $(523 \mathrm{~K})$ to black $(723 \mathrm{~K})$ in hydrogenated gas $\left(4.5 \mathrm{vol} \% \mathrm{H}_{2}\right)$, while it remains white in all the studied domain of temperature under $\mathrm{N}_{2}$.

\section{Conclusion}

The objective of this study was to estimate the potentialities of $\mathrm{SnO}_{2}$ sensors to measure weak oxygen concentrations in the range of $5-100 \mathrm{ppm}$ under $\mathrm{N}_{2}$ or hydrogenated $\mathrm{H}_{2}$ atmosphere, in the temperature range $523-723 \mathrm{~K}$.

The test bench developed for this application allowed to control well the oxygen contents in the range $5-100 \mathrm{ppm}$ and the temperature from $523 \mathrm{~K}$ to $723 \mathrm{~K}$, but only under nitrogen. Under hydrogenated atmosphere, considering experimental conditions, an important oxygen conversion occurs in the furnace as predicted by the thermodynamic calculations. In nitrogen, $\mathrm{SnO}_{2}$ sensors are able to detect oxygen traces from 5 to $100 \mathrm{ppm}$ with high sensitivity at $623 \mathrm{~K}$ and $723 \mathrm{~K}$. In hydrogen, detection of oxygen was possible at $523 \mathrm{~K}$ and $623 \mathrm{~K}$. However, the stability of $\mathrm{SnO}_{2}$ sensors for a long term application is still questionable as we observed superficial reduction of the sensing element. Operating temperature should be decreased, preferably down to $523 \mathrm{~K}$, to improve life duration of the sensor.

\section{References}

[1] C.V. Gopal Reddy, Dutta S P.K., Akbar D S.A., Detection of CO in a reducing, hydrous environment using $\mathrm{CuBr}$ as electrolyte, Sens. Actuators B: Chem. 92 (2003) 351-355.

[2] R.Mukundan, E.L. Brosha, F.H. Garzon,Alowtemperature sensor for the detection of carbon monoxide in hydrogen, Solid State Ionics 175 (2004) 497-501.

[3] O. Wurzinger, G. Reinhardt, CO-sensing properties of doped $\mathrm{SnO} 2$ sensors in $\mathrm{H} 2$ rich gases, Sens. Actuators B: Chem. 103 (2004) 104-111.

[4] Diltronic, 145 rue du Président Roosevelt 78100 Saint Germain-en-Laye, France, www.diltronic.com.

[5] Systech Instruments Ltd. 17Thame Park Business CentreWenman RoadOX9 3XA, UK, www.systechinstruments.com.

[6] E.Ye. Gutman, I.A. Myasnikov, Semiconductor method of determining oxygen 
JPV-Sensors \& Actuators B, 2009, 139(2), 298-303, doi:10.1016/j.snb.2009.03.035

microconcentrations in different gases, Sens. Actuators B: Chem. 1 (1990)

210-214.

[7] D.W. Lee, J.W. Lee, T.S. Jang, B.K. Kim,Oxygensensitivity of nanostructuredcerium oxide prepared by a thermochemical process, J. Ceram. Process. Res. 7 (2) (2006) 148-151.

[8] V.V. Malyshev, A.V. Pislyakov, I.F. Krestnikov, V.A. Krutov, S.N. Zaitsev, Sensitivity of semiconductor gas sensor to hydrogen and oxygen in an inert gas atmosphere, J. Anal. Chem. 56 (9) (2001) 864-870.

[9] G. Tournier, C. Pijolat, Influence of oxygen concentration in the carrier gas on the response of tin dioxide sensor under hydrogen and methane, Sens. Actuators B: Chem. 61 (1999) 43-50.

\section{Figures captions}

Figure 1: Photograph of $\mathrm{SnO}_{2}$ gas sensor developed by screen-printing on alumina substrate.

Figure 2: Gas composition (vol\%) versus temperature at thermodynamic equilibrium of $\mathrm{H}_{2}-\mathrm{O}_{2}-\mathrm{N}_{2}$ system with initial composition of $4.5 \mathrm{vol} \% \mathrm{H}_{2}$ and $\mathrm{O}_{2}$ contents fixed at (a) 5 ppm and (b) $2.25 \times 10^{4} \mathrm{ppm}$.

Figure 3: $\mathrm{SnO}_{2}-\mathrm{Sn}$ contents (mol\%) versus temperature at thermodynamic equilibrium in 4.5 vol\% $\mathrm{H}_{2}$ balanced in $\mathrm{N}_{2}$, with $\mathrm{O}_{2}$ contents fixed at (a) $5 \mathrm{ppm}$ and (b) $1 \mathrm{O}^{3} \mathrm{ppm}$.

Figure 4: Dynamic $\mathrm{SnO}_{2}$ response (conductance $\mathrm{G}$ versus time) at $523 \mathrm{~K}$ towards increasing $\mathrm{O}_{2}$ concentration steps in $\mathrm{N}_{2}$ for two injection cycles.

Figure 5: Dynamic $\mathrm{SnO}_{2}$ response (conductance $\mathrm{G}$ versus time) at $623 \mathrm{~K}$ towards increasing $\mathrm{O}_{2}$ concentration steps in $\mathrm{N}_{2}$, for 3 injection cycles.

Figure 6: Relative response versus injected $\mathrm{O}_{2}$ concentration in $\mathrm{N}_{2}$ at $523 \mathrm{~K}, 623 \mathrm{~K}$ and $723 \mathrm{~K}$.

Figure 7: Dynamic $\mathrm{SnO}_{2}$ response (conductance $\mathrm{G}$ versus time) at $523 \mathrm{~K}$ towards increasing $\mathrm{O}_{2}$ concentration steps in $4.5 \mathrm{vol} \% \mathrm{H}_{2}$ balanced with nitrogen for three injection cycles.

Figure 8: Dynamic $\mathrm{SnO}_{2}$ response (conductance $\mathrm{G}$ versus time) at $623 \mathrm{~K}$, towards increasing $\mathrm{O}_{2}$ concentration steps in 4.5 vol\% $\mathrm{H}_{2}$, for 3 injection cycles.

Figure 9: $X$-ray diffraction patterns of the sensing layer after tests at $723 \mathrm{~K}$ in $4.5 \mathrm{vol \%} \mathrm{H}_{2}$.

Figure 10: Comparison of relative responses versus $\mathrm{O}_{2}$ concentrations measured at the outlet of the bench, at various temperatures, either in $\mathrm{N}_{2}$ or in $4.5 \mathrm{vol} \% \mathrm{H}_{2}$.

\section{Tables captions}

Table 1: Comparison of injected oxygen concentrations (furnace inlet) with outlet ones measured by a SYSTECH probe in $\mathrm{N}_{2}$ and $4.5 \mathrm{vol} \% \mathrm{H}_{2}$ (gas flow $5 \mathrm{l} / \mathrm{h}$ ), at various temperatures (293-723 $\mathrm{K}$ ), without any sensor inside the furnace.

Table 2: Comparison of injected oxygen concentrations (furnace inlet) with outlet ones measured by a SYSTECH probe in 4.5 vol\% $\mathrm{H}_{2}$ (gas flow $5 \mathrm{l} / \mathrm{h}$ ), at various temperatures $(293-723 \mathrm{~K})$, without and with sensor inside the furnace 


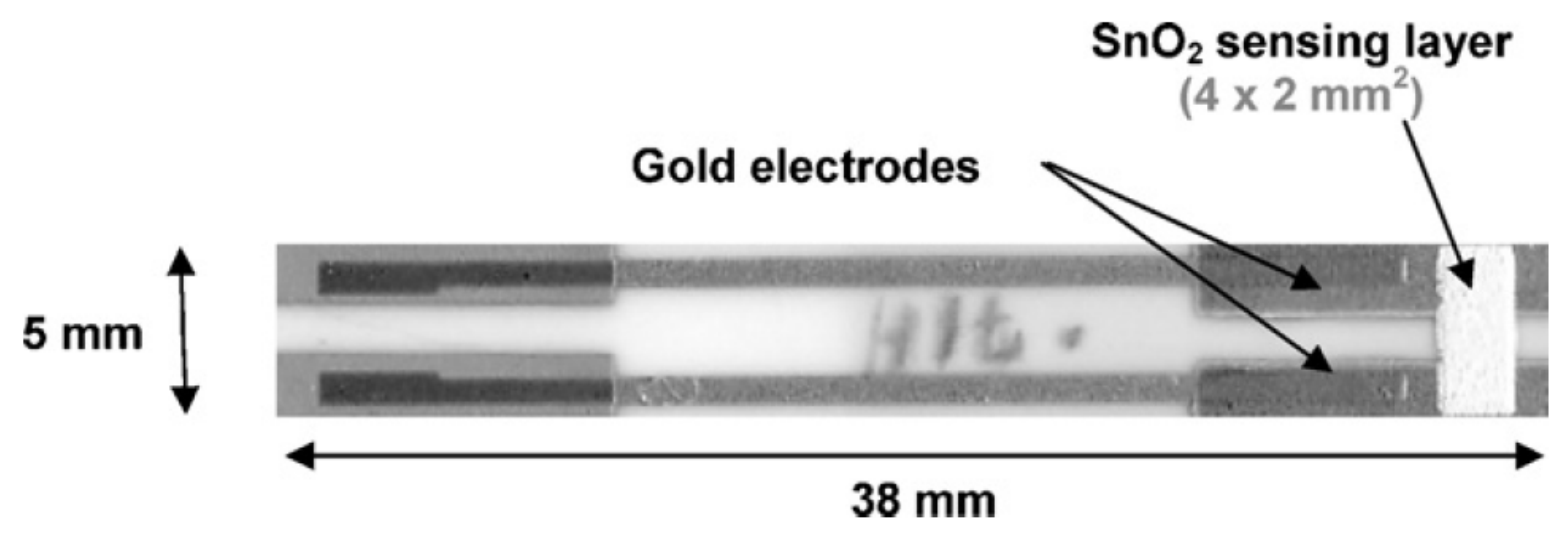

Figure 1

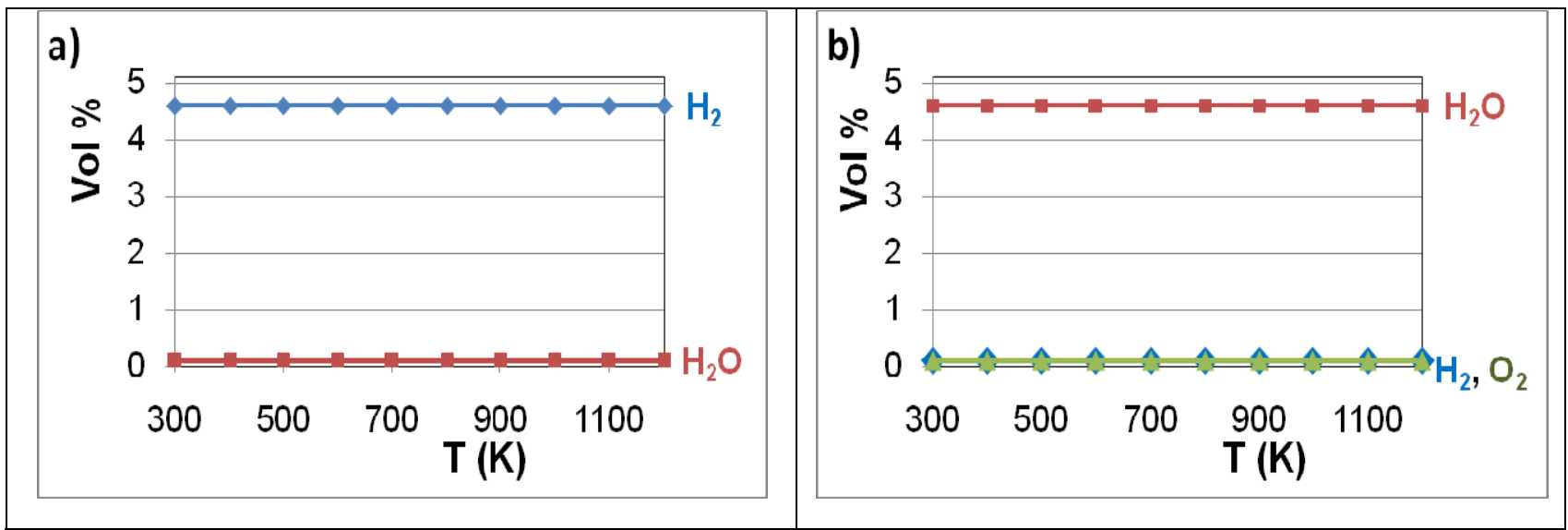

Figure 2

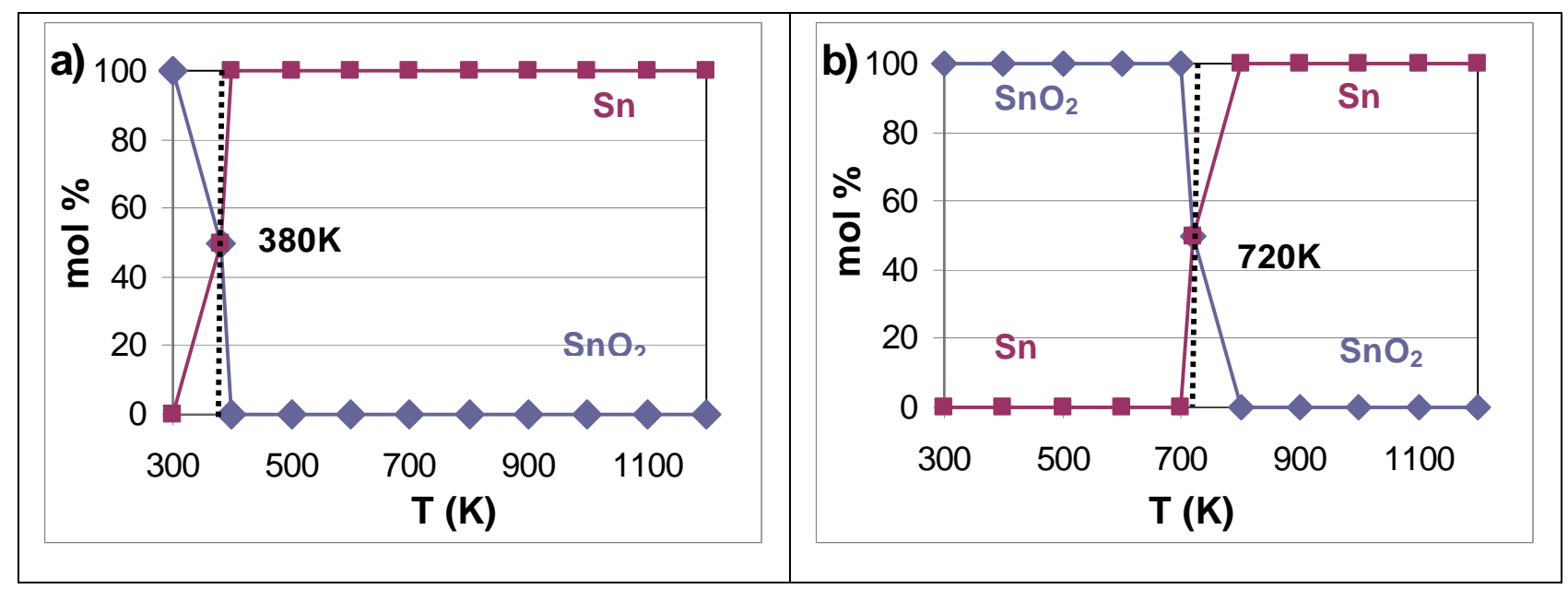

Figure 3 
JPV-Sensors \& Actuators B, 2009, 139(2), 298-303, doi:10.1016/j.snb.2009.03.035

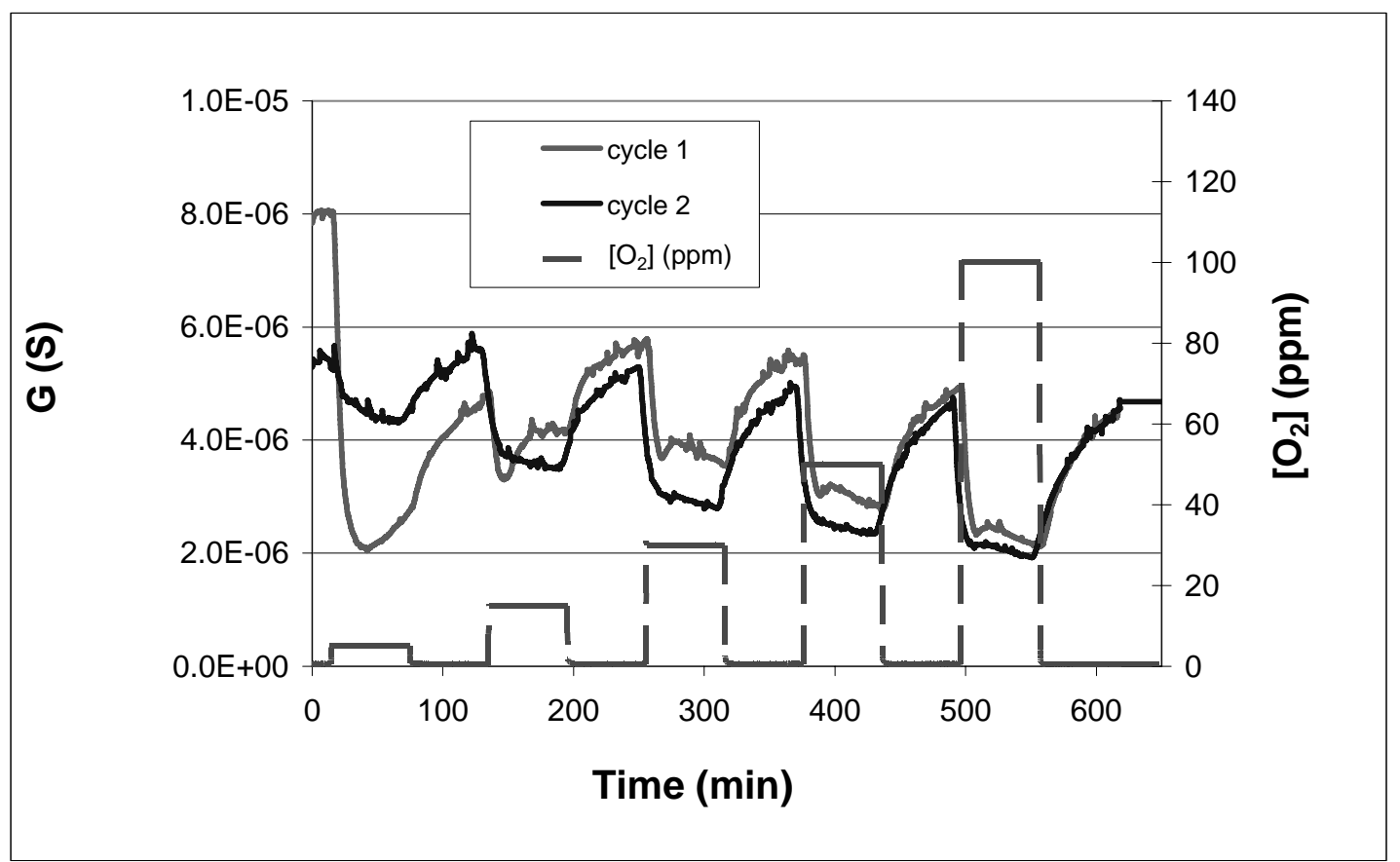

Figure 4

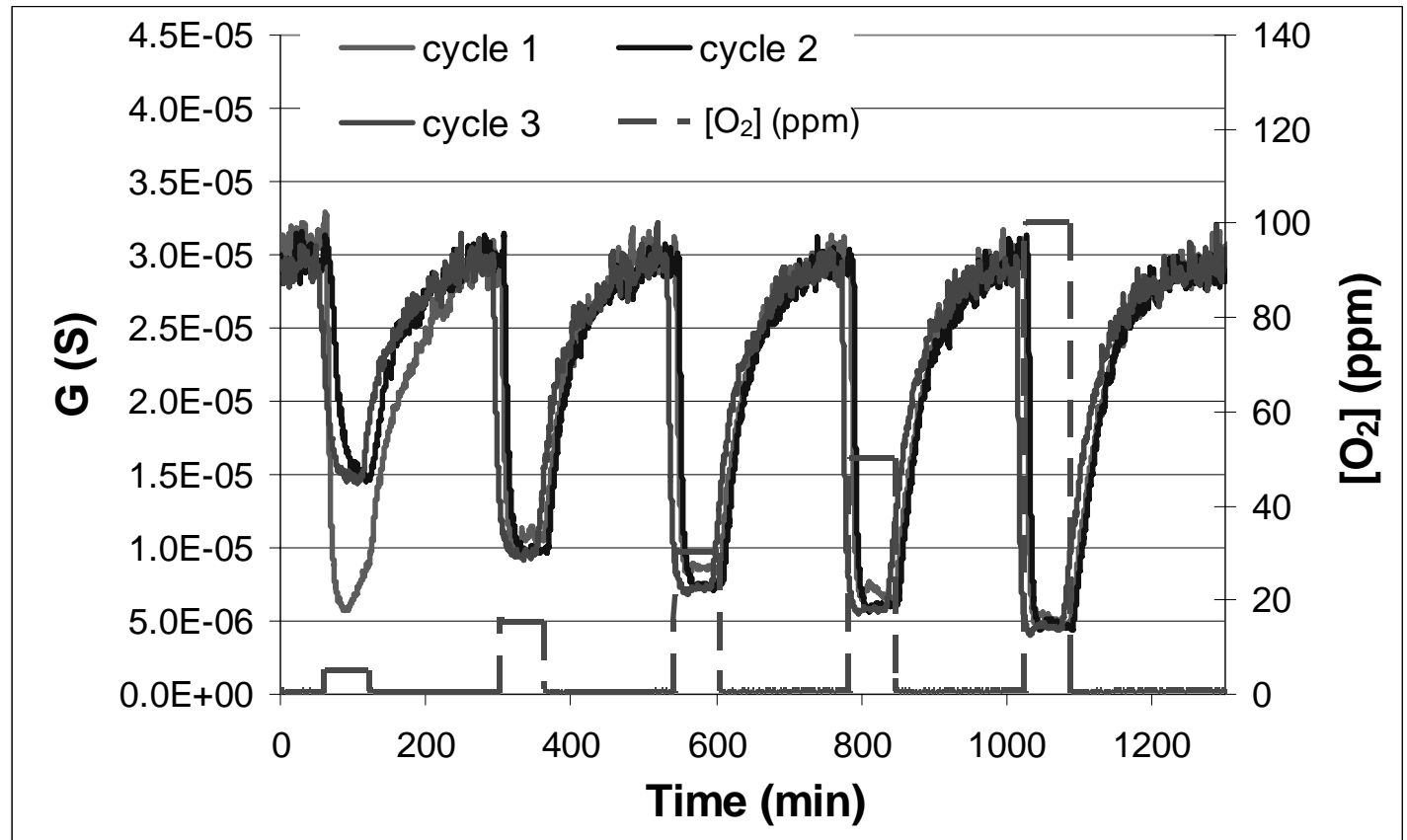

Figure 5 
JPV-Sensors \& Actuators B, 2009, 139(2), 298-303, doi:10.1016/j.snb.2009.03.035 5

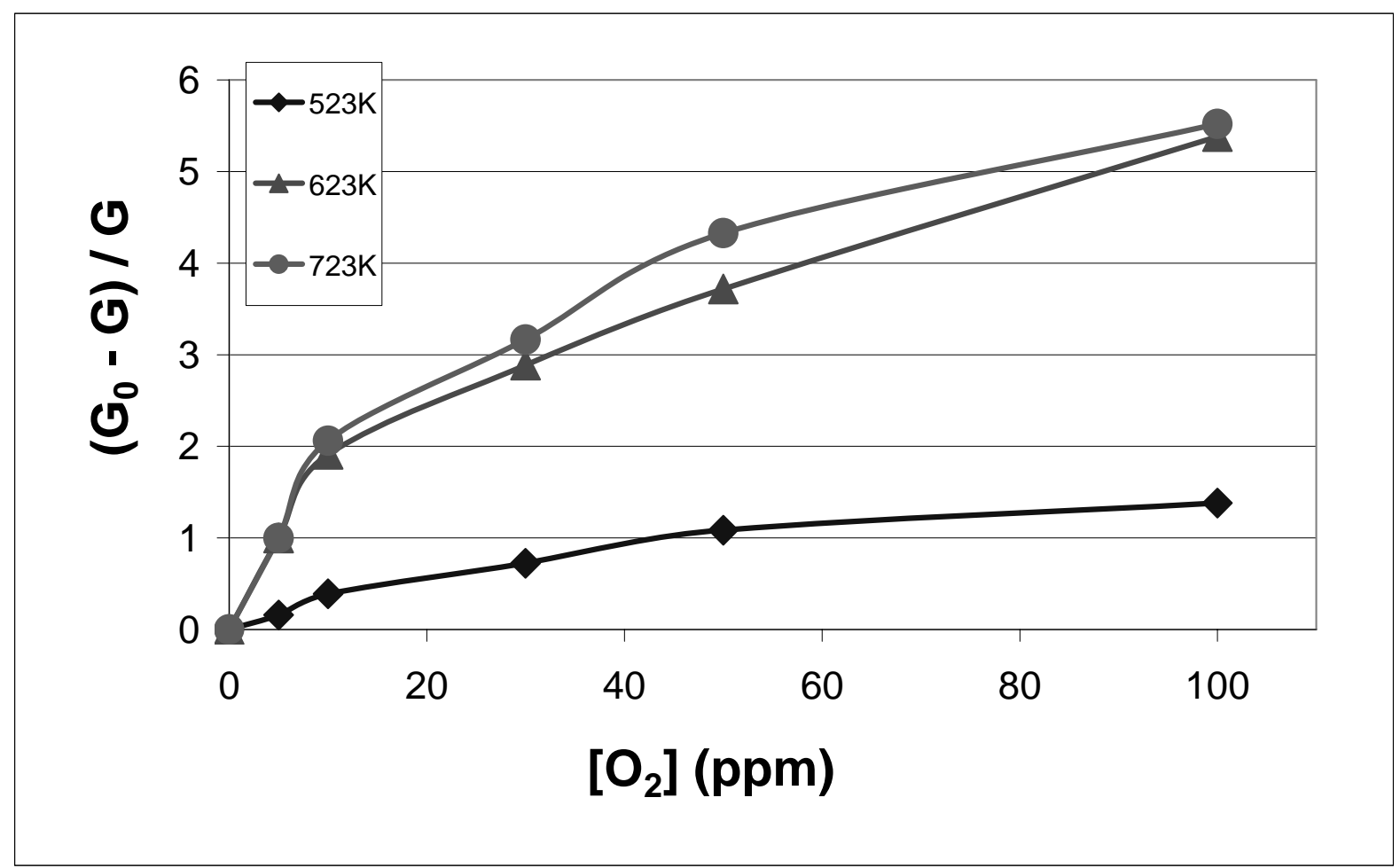

Figure 6

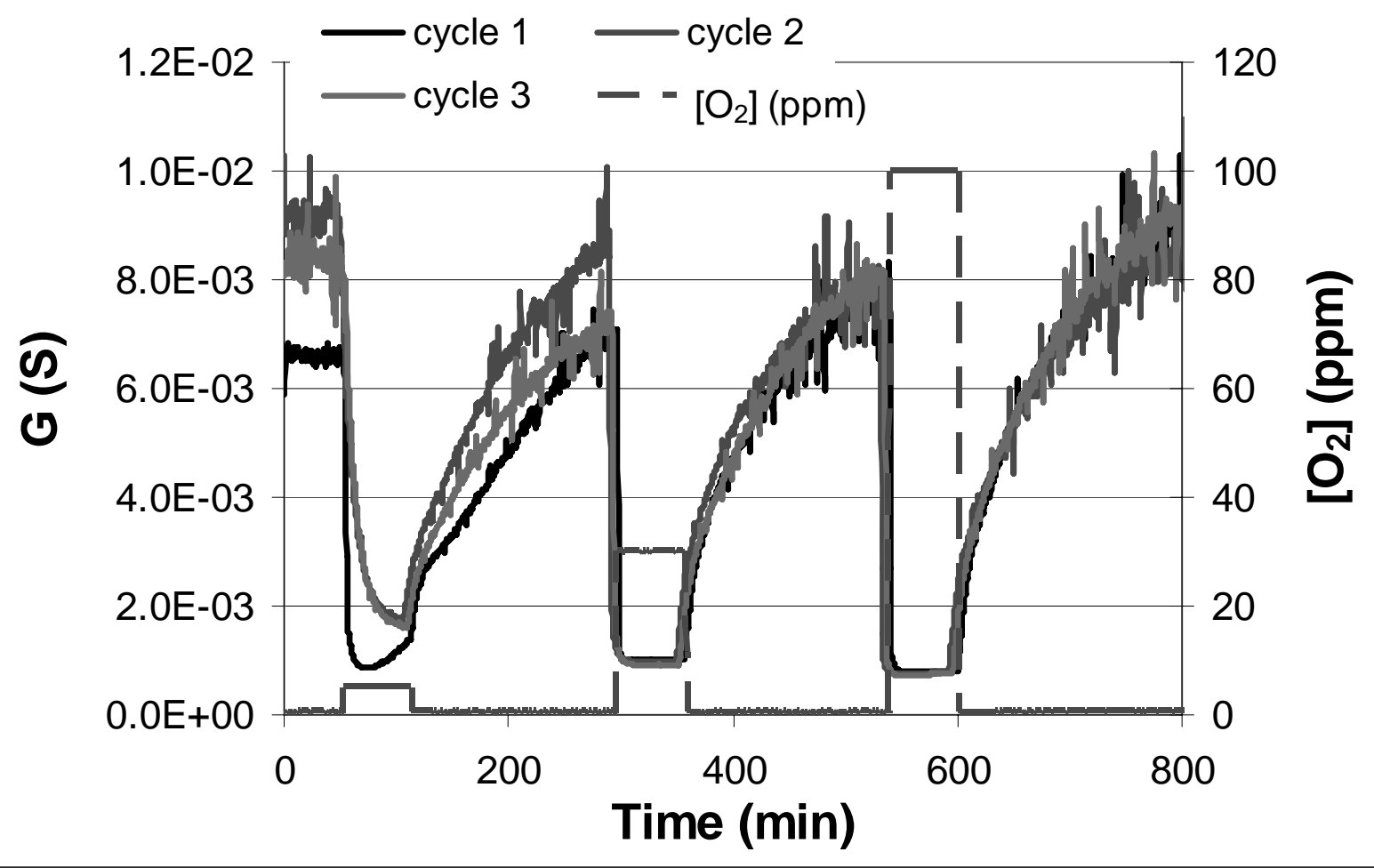

Figure 7 
JPV-Sensors \& Actuators B, 2009, 139(2), 298-303, doi:10.1016/j.snb.2009.03.035

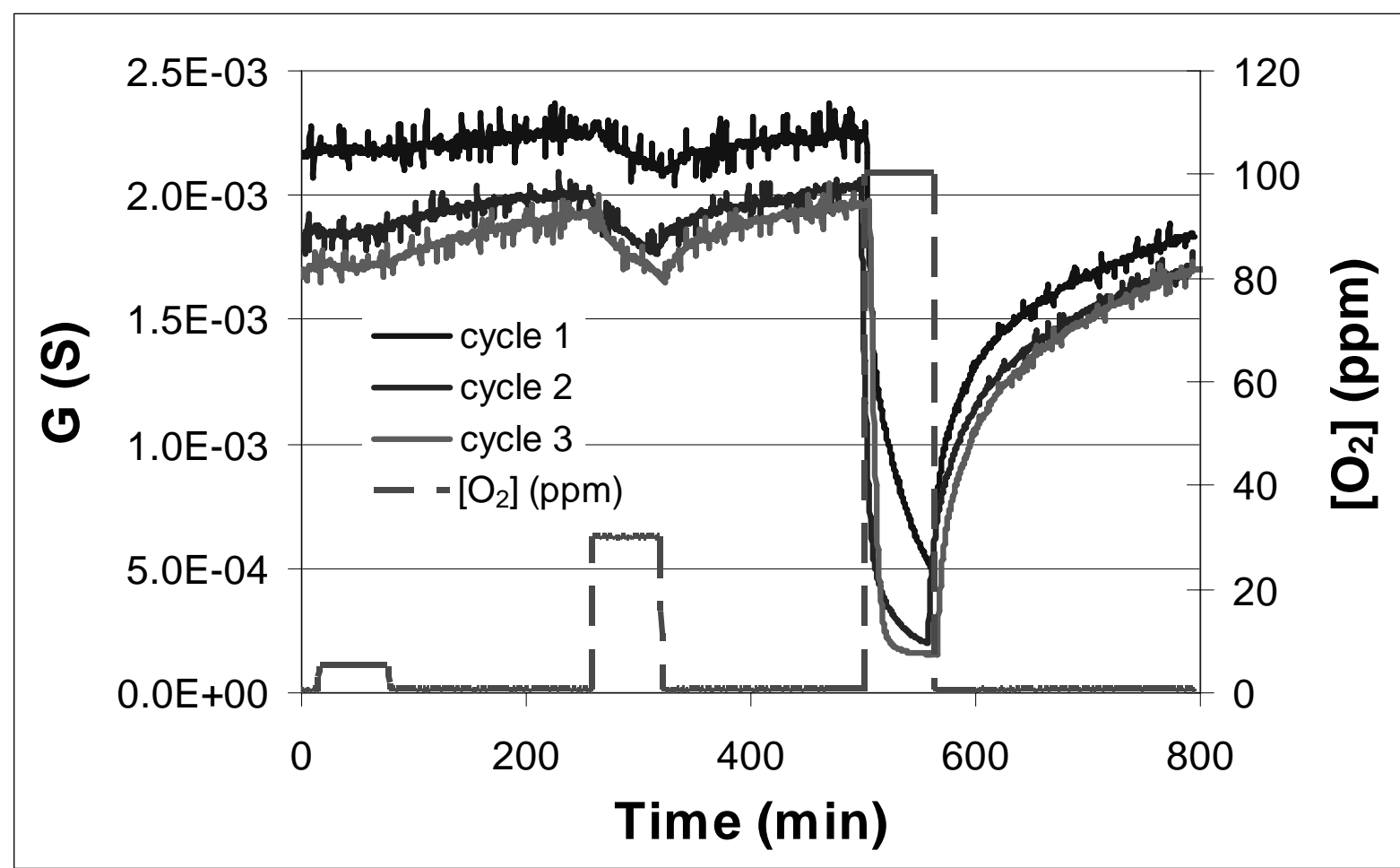

Figure 8

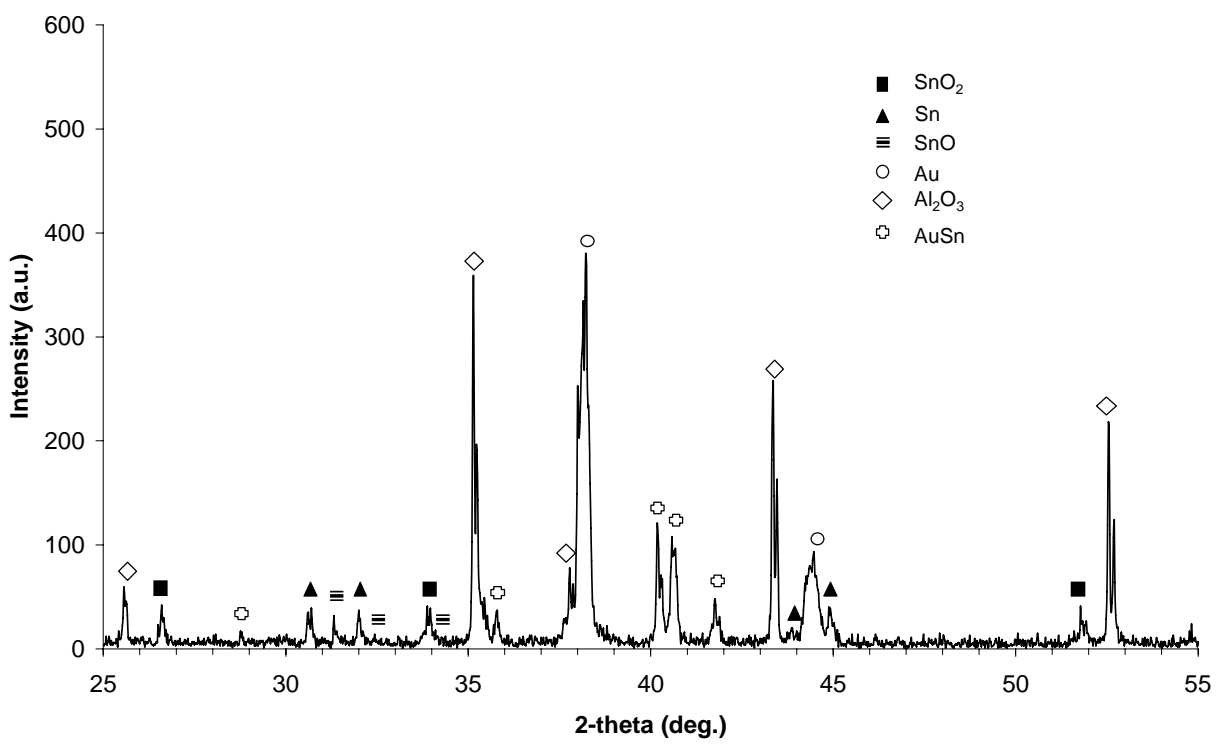

Figure 9 
JPV-Sensors \& Actuators B, 2009, 139(2), 298-303, doi:10.1016/j.snb.2009.03.035

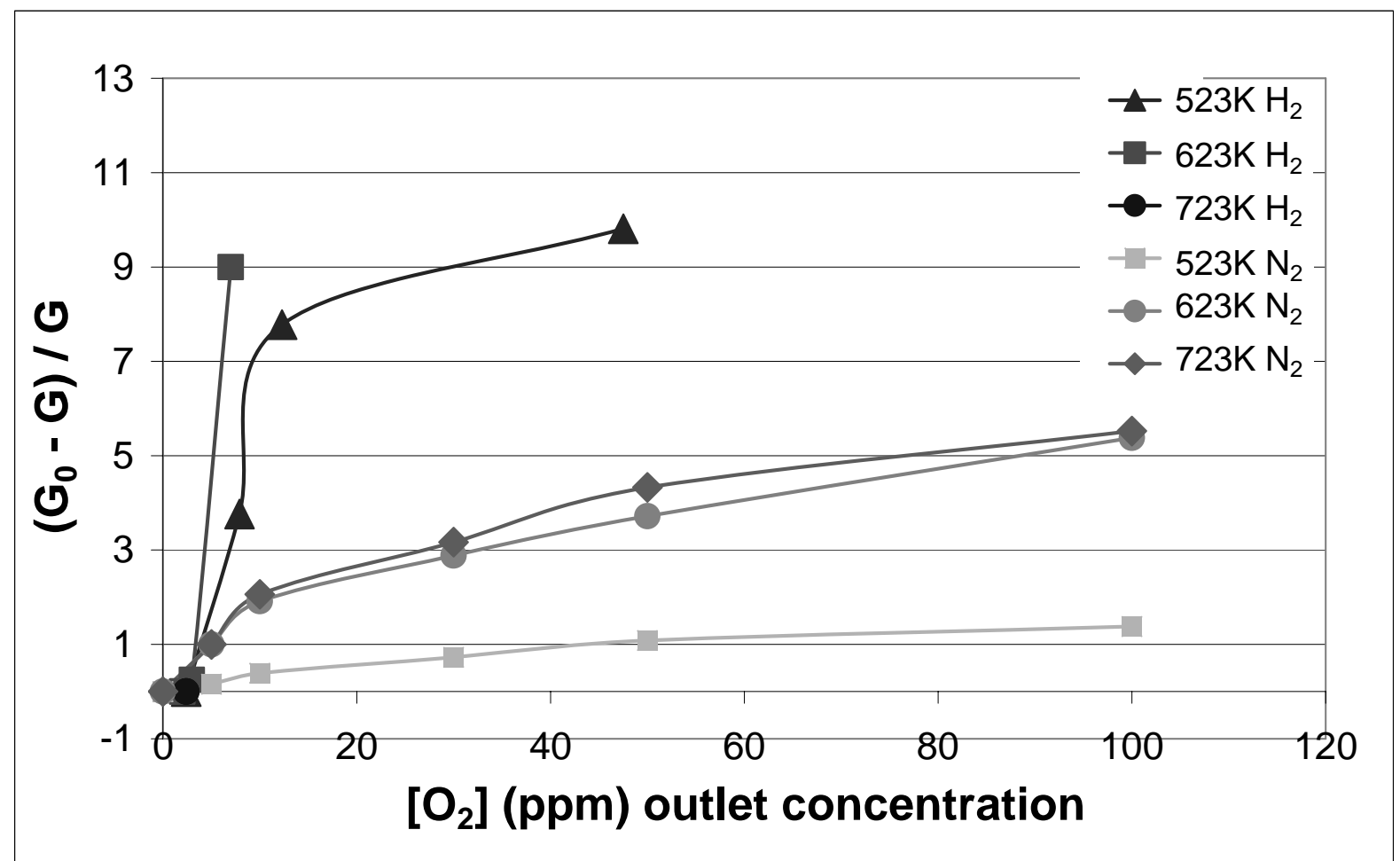

Figure 10

Table 1

\begin{tabular}{|c|c|c|c|}
\hline \multirow[t]{2}{*}{$\mathrm{T}(\mathrm{K})$} & \multirow[t]{2}{*}{ Gas environment } & \multicolumn{2}{|c|}{$\left[\mathrm{O}_{2}\right](\mathrm{ppm})$ (without sensor in furnace) } \\
\hline & & Inlet injection & Outlet measurement \\
\hline \multirow[t]{4}{*}{293} & \multirow[t]{4}{*}{$\mathrm{N}_{2}$} & 0 & 6 \\
\hline & & 5 & 11 \\
\hline & & 30 & 33 \\
\hline & & 100 & 98 \\
\hline \multirow[t]{4}{*}{293} & \multirow[t]{4}{*}{$\mathrm{N}_{2}+4.5 \% \mathrm{H}_{2}$} & 0 & 5 \\
\hline & & 5 & 9 \\
\hline & & 30 & 30 \\
\hline & & 100 & 97 \\
\hline \multirow[t]{4}{*}{523} & \multirow[t]{4}{*}{$\mathrm{N}_{2}+4.5 \% \mathrm{H}_{2}$} & 0 & 4 \\
\hline & & 5 & 6 \\
\hline & & 30 & 24 \\
\hline & & 100 & 81 \\
\hline \multirow[t]{4}{*}{723} & \multirow[t]{4}{*}{$\mathrm{N}_{2}+4.5 \% \mathrm{H}_{2}$} & 0 & 4 \\
\hline & & 5 & 4 \\
\hline & & 30 & 4 \\
\hline & & 100 & 4 \\
\hline \multirow[t]{2}{*}{723} & \multirow[t]{2}{*}{$\mathrm{N}_{2}$} & 100 & $74(5 \mathrm{l} / \mathrm{h})$ \\
\hline & & 100 & $91(12 \mathrm{l} / \mathrm{h})$ \\
\hline
\end{tabular}


JPV-Sensors \& Actuators B, 2009, 139(2), 298-303, doi:10.1016/j.snb.2009.03.035

Table 2

\begin{tabular}{|c|c|c|c|}
\hline \multirow[t]{2}{*}{$\mathrm{T}(\mathrm{K})$} & \multicolumn{3}{|c|}{$\left[\mathrm{O}_{2}\right](\mathrm{ppm})$} \\
\hline & Inlet injection & $\begin{array}{l}\text { Outlet measurement } \\
\text { WITHOUT sensor }\end{array}$ & $\begin{array}{l}\text { Outlet measurement } \\
\text { WITH sensor }\end{array}$ \\
\hline \multirow[t]{3}{*}{523} & $\mathrm{O}$ & 4 & 2 \\
\hline & 30 & 24 & 12 \\
\hline & 100 & 81 & 47 \\
\hline \multirow[t]{3}{*}{623} & O & - & 2 \\
\hline & 30 & - & 3 \\
\hline & 100 & - & 7 \\
\hline \multirow[t]{3}{*}{723} & O & 4 & 2 \\
\hline & 30 & 4 & 2 \\
\hline & 100 & 4 & 2 \\
\hline
\end{tabular}

